\title{
COPPER AVAILABILITY AS RELATED TO SOIL COPPER FRACTIONS IN OXISOLS UNDER LIMING
}

\author{
Clístenes Williams Araújo do Nascimento; Renildes Lúcio Ferreira Fontes²; Adilson César \\ Fortes Dias Melicio² \\ ${ }^{1}$ Depto. de Agronomia - UFRPE - CEP: $52171-900$ - Recife, PE. \\ ${ }^{2}$ Depto. de Solos e Nutrição de Plantas - UFV - CEP: 36571-000 - Viçosa, MG. \\ *Corresponding author <cwan@bol.com.br>
}

\begin{abstract}
The knowledge of the chemical forms of copper in soils and the relationships of these forms with soil copper availability are important for predicting the copper behavior in the soil-plant system. The present work studies the influence of liming on the available contents of copper as well as on the forms of copper fractions in six types of Oxisols. Soil samples, with and without liming, received copper at rates of 0.0, 20.0 and $40.0 \mathrm{mg} \mathrm{dm}^{3}$ and remained incubated for 30 days. Then, available copper was extracted with Mehlich-1, Mehlich-3, DTPA and EDTA solutions, and analyzed by atomic absorption spectrophotometry. Additionally, soil samples were extracted in a sequential procedure to determine $\mathrm{Cu}$ in fractions of soil, as follows: exchangeable-Cu fraction, organic matter-Cu fraction, Mn oxide-Cu fraction, amorphous Fe oxide-Cu fraction, crystalline Fe oxide-Cu fraction, residual-Cu fraction, and the total Cu content in the soil. Soil samples to which $\mathrm{Cu}$ was added presented higher $\mathrm{Cu}$ retention in the organic matter fraction with a small percentage retained in the exchangeable-Cu fraction. Liming resulted in a decrease of $\mathrm{Cu}$ in the exchangeable and organic matter fractions and an increase in the $\mathrm{Fe}$ and $\mathrm{Mn}$ oxide fractions and in the residual fraction. Without liming, the organic matter fraction presented the highest contribution to Cu content found in the soil extracts obtained with all extractors, except EDTA. For treatments with liming, Cu contents in the organic matter fraction were better correlated to Cu contents in extracts obtained with DTPA and Mehlich-3.
\end{abstract}

Key words: fractioning, micronutrients, soil analysis

\section{CALAGEM E OS TEORES DISPONÍVEIS E AS FRAÇÕES DE COBRE EM LATOSSOLOS}

\begin{abstract}
RESUMO: O conhecimento das formas químicas em que se encontra o cobre em solos, e suas relações com os teores disponíveis, são importantes para a previsão do seu comportamento no sistema solo-planta. Nesse sentido, este trabalho estuda a influência da calagem sobre os teores disponíveis e sobre o fracionamento de Cu em amostras de seis Latossolos. Essas amostras, submetidas ou não a calagem, receberam o elemento nas doses de $0,0,20,0$ e 40,0 $\mathrm{mg} \mathrm{dm}^{-3}$ e foram incubadas por 30 dias. Terminada a incubação, procedeu-se a extração de Cu utilizando-se os extratores Mehlich-1, Mehlich-3, DTPA e EDTA. As amostras foram submetidas a um fracionamento que separou o Cu nas frações trocável, matéria orgânica, óxido de manganês, óxido de ferro amorfo, óxido de ferro cristalino e residual, além dos teores totais. Com sua aplicação ao solo o Cu foi retido, principalmente, na fração matéria orgânica, com pequena porcentagem retida na fração trocável. A calagem provocou redução nas frações trocável e matéria orgânica e aumento nas frações óxido de ferro, óxido de manganês e residual. Para os solos sem calagem, a fração matéria orgânica foi a que mais contribuiu para os teores determinados pelos extratores, com exceção do EDTA. Nos solos com calagem, 0 Cu ligado à matéria orgânica foi melhor correlacionado com os teores obtidos pelo DTPA e Mehlich-3.

Palavras-chave: fracionamento, micronutrientes, análise de solo
\end{abstract}

\section{INTRODUCTION}

Initial efforts to establish methods for analysis of copper in soils focused the utilization of aqueous, diluted solutions of acids and bases, and diluted salts, which would simulate the root extraction power. These solutions were modified through the addition of anions and cations to displace exchangeable micronutrients, and of chelating agents which increase micronutrient solubility or compete with the organic matter for micronutrient complexation (Sims \& Johnson, 1991).
Simple chemical extractions have been extensively used for the determination of micronutrient availability in soils. However, as the amount of extracted micronutrients varies with soil type, these extractions have presented variable degree of success to make micronutrient deficiency or toxicity diagnoses for plants. The knowledge of the chemical forms in which micronutrients are extracted from the soil, for each extraction method, may help to understand the efficiency of each method (Zhu \& Alva, 1993).

To select a chemical solution which is able to remove the nutrient quantity which represents their 
promptly and potentially available forms, the understanding of the various forms of the elements in the soils is required (Sims \& Johnson, 1991). Therefore, methods of extraction which fractionate the soil and indicate the nutrient form more available to plants, as well as, the soil characteristics and management conditions affecting nutrient availability are very important for the prediction of nutrient behavior in the soil-plant system. A soil fractionation study which allows the indication of the nutrient form that better correlates to the amount of available nutrient determined by an extraction method is also important to predict nutrient behavior in the soil-plant system.

Soil $\mathrm{pH}$ is, most of the time, the main factor controlling $\mathrm{Cu}$ availability for plants, once increases of soil $\mathrm{pH}$ result in decreases of $\mathrm{Cu}$ availability. The negative effect of liming on $\mathrm{Cu}$ availability occurs, mainly, due to the increase in the soil cation exchange capacity which depends on the presence of $\mathrm{pH}$ dependent charges in the soil (Alloway, 1990). As the $\mathrm{pH}$ increases, the number of negative $\mathrm{pH}$ dependent charges also increases, the negative charge density at the surface of the colloid increases and the $\mathrm{Cu}$ availability for the plant decreases. Therefore, it is important to know how the $\mathrm{pH}$ affects the distribution of $\mathrm{Cu}$ in the different fractions of the soil (Shuman, 1985).
The present work was carried out to study the influence of liming on the distribution of copper among the soil fractions. Additionally, the effect of liming was evaluated on the recovering rate of copper extracting the element from six Oxisols by chemical extractors.

\section{MATERIAL AND METHODS}

Samples from six soil types $(0-20 \mathrm{~cm}$ layer), selected based on the basis of clay and organic matter contents, were collected at municipalities of the Minas Gerais State, Brazil (Table 1). They were: Rhodic Haplustox - LV1 (Sete Lagoas), Rhodic Haplustox - LV2 (São Sebastião do Paraíso), Rhodic Haplustox - LV3 (São Sebastião do Paraíso), Typic Haplustox - LVA1 (João Pinheiro), Typic Haplustox - LVA2 (Viçosa) and Humic Haplustox - LVA3 (Viçosa).

Soil samples were homogenized and passed through a $2.0 \mathrm{~mm}$ sieve; sub-samples of $600 \mathrm{~cm}^{3}$ received the treatments. Half of the sub-samples were limed to adjust the $\mathrm{pH}$ to the 6.5 to 7.0 range, with rates of $\mathrm{CaCO}_{3}$ and $\mathrm{MgCO}_{3}$ based on an incubation study. After liming, soil samples were kept at field capacity for 15 days. Subsequently $\mathrm{Cu}$ rates were added (0.0, 20.0 and

Table 1 - Chemical and physical characterization of the soils (Rhodic Haplustox - LV1, Rhodic Haplustox - LV2, Rhodic Haplustox - LV3, Typic Haplustox - LVA1, Typic Haplustox - LVA2, Humic Haplustox - LVA3).

\begin{tabular}{|c|c|c|c|c|c|c|}
\hline Characteristic & $\mathrm{LV}_{1}$ & $\mathrm{LV}_{2}$ & $\mathrm{LV}_{3}$ & $\mathrm{LVA}_{1}$ & $\mathrm{LVA}_{2}$ & $\mathrm{LVA}_{3}$ \\
\hline$\overline{\mathrm{pH} \mathrm{H}} \mathrm{H}_{2} \mathrm{O}(1: 2,5)$ & 4.6 & 4.4 & 4.7 & 4.0 & 4.1 & 4.2 \\
\hline$P\left(\mathrm{mg} \mathrm{dm}^{-3}\right)^{1}$ & 4.0 & 0.0 & 0.0 & 1.3 & 0.0 & 1.9 \\
\hline $\mathrm{K}\left(\mathrm{mg} \mathrm{dm^{-3 }}\right)^{1}$ & 20 & 59 & 16 & 21 & 15 & 15 \\
\hline $\mathrm{Ca}^{2+}\left(\mathrm{cmol}_{\mathrm{c}} \mathrm{dm}^{-3}\right)^{2}$ & 1.24 & 0.55 & 0.72 & 0.08 & 0.02 & 0.46 \\
\hline $\mathrm{Mg}^{2+}\left(\mathrm{cmol}_{\mathrm{c}} \mathrm{dm}^{-3}\right)^{2}$ & 0.20 & 0.11 & 0.23 & 0.04 & 0.02 & 0.13 \\
\hline $\mathrm{Al}^{3+}\left(\mathrm{cmol}_{\mathrm{c}} \mathrm{dm}^{-3}\right)^{2}$ & 0.50 & 0.10 & 0.20 & 0.90 & 1.20 & 1.90 \\
\hline $\mathrm{H}+\mathrm{Al}\left(\mathrm{cmol}_{\mathrm{c}} \mathrm{dm}^{-3}\right)^{3}$ & 8.3 & 11.9 & 6.6 & 6.6 & 8.9 & 7.6 \\
\hline $\mathrm{Zn} \quad\left(\mathrm{mg} \mathrm{dm}^{-3}\right)^{1}$ & 1.21 & 0.46 & 0.37 & 0.40 & 0.18 & 1.14 \\
\hline $\mathrm{Fe}\left(\mathrm{mg} \mathrm{dm^{3 }}\right)^{1}$ & 46.3 & 53.7 & 47.4 & 74.1 & 108.7 & 80.1 \\
\hline $\mathrm{Cu}\left(\mathrm{mg} \mathrm{dm}^{3}\right)^{1}$ & 0.77 & 6.57 & 8.73 & 0.40 & 0.12 & 0.22 \\
\hline $\operatorname{Mn}\left(\mathrm{mg} \mathrm{dm}^{-3}\right)^{1}$ & 29.0 & 39.0 & 34.0 & 6.3 & 2.3 & 6.1 \\
\hline CECefetiva $\left(\mathrm{cmol}_{\mathrm{c}} \mathrm{dm}^{-3}\right)$ & 2.45 & 0.91 & 1.19 & 1.07 & 1.28 & 2.53 \\
\hline CECtotal $\left(\mathrm{cmol} \mathrm{dm}^{-3}\right)$ & 10.25 & 12.71 & 7.59 & 6.77 & 8.98 & 8.23 \\
\hline V (\%) & 14.5 & 6.4 & 13.0 & 2.5 & 0.87 & 7.7 \\
\hline m (\%) & 20.4 & 11.0 & 16.8 & 84.1 & 93.81 & 75.1 \\
\hline O.C. $\left(\mathrm{g} \mathrm{kg}^{-1}\right)^{5}$ & 28.7 & 13.92 & 17.0 & 8.7 & 18.6 & 112.5 \\
\hline P-rem $\left(\mathrm{g} \mathrm{kg}^{-1}\right)^{6}$ & 7.48 & 3.61 & 6.54 & 28.65 & 2.76 & 1.34 \\
\hline $\mathrm{SiO}_{2}\left(\mathrm{~g} \mathrm{~kg}^{-1}\right)^{7}$ & 183 & 48 & 74 & 128 & 198 & 102 \\
\hline $\mathrm{Al}_{2} \mathrm{O}_{3}\left(\mathrm{~g} \mathrm{~kg}^{-1}\right)^{7}$ & 318.0 & 341.1 & 321.0 & 168.7 & 288.5 & 190.5 \\
\hline $\mathrm{Fe}_{2} \mathrm{O}_{3}\left(\mathrm{~g} \mathrm{~kg}^{-1}\right)^{7}$ & 124.2 & 338.4 & 304.1 & 46.0 & 126.6 & 53.7 \\
\hline $\mathrm{TiO}_{2}\left(\mathrm{~g} \mathrm{~kg}^{-1}\right)^{7}$ & 7.1 & 67.5 & 61.5 & 5.1 & 19.3 & 6.4 \\
\hline $\mathrm{MnO}\left(\mathrm{g} \mathrm{kg}^{1}\right)^{7}$ & 0.3 & 1.5 & 1.5 & 0.1 & 0.1 & 0.1 \\
\hline $\mathrm{P}_{2} \mathrm{O}_{5}\left(\mathrm{~g} \mathrm{~kg}^{-1}\right)^{7}$ & 2.1 & 2.4 & 2.2 & 0.3 & 0.6 & 1.1 \\
\hline Thick sand $\left(\mathrm{g} \mathrm{kg}^{-1}\right)^{8}$ & 110 & 70 & 90 & 400 & 150 & 460 \\
\hline Fine sand $\left(\mathrm{g} \mathrm{kg}^{-1}\right)^{8}$ & 40 & 230 & 300 & 230 & 100 & 140 \\
\hline Silt $\left(\mathrm{g} \mathrm{kg}^{-1}\right)^{8}$ & 140 & 240 & 190 & 50 & 70 & 160 \\
\hline Clay $\left(\mathrm{g} \mathrm{kg}^{1}\right)^{8}$ & 710 & 460 & 420 & 320 & 680 & 240 \\
\hline
\end{tabular}

${ }^{1}$ Mehlich-1 (De Filippo \& Ribeiro, 1997). ${ }^{2} \mathrm{KCl} 1 \mathrm{~mol} \mathrm{~L}{ }^{-1}$ (De Filippo \& Ribeiro, 1997). ${ }^{3} \mathrm{CaOAc} 0.5 \mathrm{~mol} \mathrm{~L}^{-1}$ (De Filippo \& Ribeiro, 1997). ${ }^{4}$ Tri-acid attack (Ure, 1990). ${ }^{5}$ Walkley-Black (De Filippo \& Ribeiro, 1997). ${ }^{6}$ Remaining-P (Alvarez V. et al., 2000). ${ }^{7}$ Sulfuric digestion (Vettori, 1969). ¿EMBRAPA (1997). 
$40.0 \mathrm{mg} \mathrm{dm}^{-3}$ ) as $\mathrm{CuCl}_{2} \cdot 2 \mathrm{H}_{2} \mathrm{O}$ and samples were maintained incubated, at field capacity, for others 30 days.

After 30 days incubation soil samples were again passed through a $2 \mathrm{~mm}$ sieve and extracted with Mehlich1 (De Filippo \& Ribeiro, 1997), Mehlich-3 (Mehlich, 1984), DTPA (Lindsay \& Norvell, 1978) and EDTA (Lantmann $\&$ Meurer, 1982). Copper in the extracts was determined by atomic absorption spectrophotometry.

Additionally, extraction was performed sequentially, based on Shuman (1985), except the amorphous Fe oxide fraction which was extracted based on Chao \& Zhou (1983). This sequential fractionation separated $\mathrm{Cu}$ in the following fractions: exchangeable, bounded to organic matter, to manganese oxide, amorphous iron oxide and crystalline iron oxide. The total contents of micronutrients was determined after acid digestion (Ure, 1990). The sequential fractionation method used consisted, in detail, of:

Exchangeable Fraction (Ex) - In $50 \mathrm{~mL}$ centrifuge tube, a mixture of $5.0 \mathrm{~g}$ of soil and $20.0 \mathrm{~mL}$ of $1 \mathrm{~mol} \mathrm{~L}^{-1}$ $\mathrm{Mg}\left(\mathrm{NO}_{3}\right)_{2}$ was shacken for two hours; the mixture was centrifuged for $10 \mathrm{~min}$ at $3000 \mathrm{rpm}$ and the supernatant filtered and separated; $20.0 \mathrm{~mL}$ of distilled water were added, another shacking procedure was performed during $3 \mathrm{~min}$, a new centrifugation was performed and the supernatant filtered and separated again. The two supernatants were combined and stored for analysis. The sequential extraction continued in the remaining of the soil sample.

Organic Matter Fraction (OM) - To the Ex free soil sample $10 \mathrm{~mL}$ of $\mathrm{NaClO} 5-6 \%$ at $\mathrm{pH} 8.5$ were added; the system was heated to $100^{\circ} \mathrm{C}$ during $30 \mathrm{~min}$., shacking from time to time; the sample was, thereafter, centrifuged and the supernatant filtered. This procedure was repeated twice and the three separated supernatants were combined. To the sample in the centrifuge tube, 10 $\mathrm{mL}$ of distilled water were added and after shacking for $3 \mathrm{~min}$ the mixture was centrifuged, filtered, and the separated supernatant was added to the three combined extracts from the $\mathrm{NaClO}$ extraction and stored for analysis. The sequential extraction continued in the remaining soil sample.

Manganese Oxide Fraction (MnOx) - To the remaining soil sample $30.0 \mathrm{~mL}$ of $\mathrm{NH} \mathrm{OH} . \mathrm{HCl}$ (hydroxylamine hydrochloride) $0.1 \mathrm{~mol} \mathrm{~L}^{-1}$, at $\mathrm{pH}^{2} 2.0$ were added, and the mixture was shacken for $30 \mathrm{~min}$, centrifuged and filtered; the separated supernatant was stored for analysis. To continue the sequential extraction, $15 \mathrm{~mL}$ of distilled water were added to the centrifuge tube, shacken for $3 \mathrm{~min}$ and the the supernatant discharged.

Amorphous Iron Oxide Fraction (AFeOx) - To the $\mathrm{OM}$ free soil sample $30.0 \mathrm{~mL}$ of $\mathrm{NH}_{2} \mathrm{OH} . \mathrm{HCl}$ (hydroxylamine hydrochloride) $0.1 \mathrm{~mol} \mathrm{~L}^{-1}$ plus $\mathrm{HCl} 0.25$ mol $\mathrm{L}^{-1}$, at $\mathrm{pH} 3.0$ were added, and the mixture was shacken for $30 \mathrm{~min}$, centrifuged and filtered; the separated supernatant was stored for analysis. To continue the sequential extraction, $15 \mathrm{~mL}$ of distilled water were added to the centrifuge tube, shacken for $3 \mathrm{~min}$ and the supernatant discharged.

Crystalline Iron Oxide Fraction (CFeOx) - To the AFeOx free soil sample $30.0 \mathrm{~mL}$ of $\left(\mathrm{NH}_{4}\right)_{2} \mathrm{C}_{2} \mathrm{O}_{4}$ (ammonium oxalate) $0.2 \mathrm{~mol} \mathrm{~L}^{-1}+\mathrm{H}_{2} \mathrm{C}_{2} \mathrm{O}_{4}$ (oxalic acid) $0.2 \mathrm{~mol} \mathrm{~L}^{-1}+$ ascorbic acid $0.01 \mathrm{~mol}^{-1}$, at $\mathrm{pH} 3.0$ were added, the mixture was heated to $100^{\circ} \mathrm{C}$ for $30 \mathrm{~min}$, shacking from time to time; thereafter centrifuged and filtered; the separated supernatant was stored for analysis.

Residual Fraction $(R)$ - Copper contents in the residual fraction were calculated by the difference between the determined total content and the summation of the contents found in the former fractions.

Total Content $(T)$ - Total content of $\mathrm{Cu}$ was determined after acid digestion of soil samples (Ure, 1990), without sequential fractionation.

The experiment was set in an entirely randomized design with six soil types, three copper rates, with and without liming, and three replications. Correlation coefficients were made for the relationship between the $\mathrm{Cu}$ contents obtained by the extractors and the $\mathrm{Cu}$ contents found in the soil fractions. Additionally, correlation coefficients were calculated for the relationship between soil characteristics and the slopes of the Recovered $\mathrm{Cu} /$ Added $\mathrm{Cu}$ ratio, for each extractor. The coefficients were tested at the 5 and $1 \%$.

\section{RESULTS AND DISCUSSION}

The Cu contents originally found in the soils (Table 2) were slightly above the $\mathrm{Cu}$ concentrations usually expected in soils which are in the 2 to $100 \mathrm{mg} \mathrm{kg}^{-1}$ range (Baker, 1990). These contents are related to the parent material and are found in higher contents in soils originated from mafic rocks (LV1, LV2 e LV3) and in lower contents in soils from granite or gneiss (LVA1, LVA2, LVA3).

For soil samples that received no $\mathrm{Cu}$ and no liming, $\mathrm{Cu}$ concentrations were present predominantly (65 to $88 \%$ ) in the Residual fraction (R) (Table 2). In the remainder fractions the distribution of retained $\mathrm{Cu}$ was $7.5 \%$ in the Crystalline $\mathrm{Fe}$ Oxides fraction (CFeOx), 7.3\% in the Organic Matter fraction (OM), and $3.5 \%$ in the Amorphous Fe Oxides fraction (AFeOx) (Table 2). Similar results for $\mathrm{Cu}$ distribution in soils were found by McLaren \& Crawford (1973a) and Sims (1986).

The $\mathrm{Cu}$ concentrations of the Exchangeable fraction in the soils without liming and with $\mathrm{Cu}$ addition (Table 2) at soil pH below 5.0 (Table 1) were low. These results indicate a high $\mathrm{Cu}$ adsorption capacity of the soils and are in agreement with Msaky \& Calvet (1990) that observed complete adsorption of the $\mathrm{Cu}$ added to soil, even at low $\mathrm{pH}$. On the other hand, the elevation of soil $\mathrm{pH}$ above 5.0 resulted in decrease of $\mathrm{Cu}$ concentration in solution (Sanders, 1982), which indicates the influence of higher $\mathrm{pH}$ values on the $\mathrm{Cu}$ sorption to the soil. The metals with higher electronegativities form stronger covalent 
bounds with oxygen atoms from minerals and, therefore, are preferentially adsorbed to them. The electronegativity values for $\mathrm{Cu}$ (1.90), $\mathrm{Zn}$ (1.65) and $\mathrm{Mn}$ (1.55) explain the higher selectivity of the soil minerals for $\mathrm{Cu}$ and the high hysteresis for the adsorption of this element to soil, as compared to the other (McBride, 1994).
For treatments without liming the $\mathrm{Cu}$ distribution corresponded to $17 \%$ in the OM fraction, $11 \%$ in the CFeOx fraction, $8 \%$ in the AFeOx fraction, $3 \%$ in the $\mathrm{MnOx}$ fraction, and only $1.4 \%$ in the Ex fraction (Table 2). The lowest value for $\mathrm{Cu}$ in the exchangeable form indicates a low affinity of soil cation exchange sites for $\mathrm{Cu}$ ions, as

Table 2 - Copper concentrations in the Exchangeable (Ex), Organic Matter (OM), Manganese Oxides (MnOx), Amorphous Fe Oxides (AFeOx), Crystalline Fe Oxides (CFeOx), Residual (R) fractions and Total content ( $T$ ), and the relative proportion of $\mathrm{Cu}$ in each fraction as related to the total $\mathrm{Cu}$ content, for three $\mathrm{Cu}$ rates, with and without liming.

\begin{tabular}{|c|c|c|c|c|c|c|c|c|c|c|c|c|c|c|}
\hline \multirow{2}{*}{ Soil } & \multirow{2}{*}{$\begin{array}{c}\text { Rate } \\
\mathrm{mg} \mathrm{dm}^{-3}\end{array}$} & \multicolumn{2}{|c|}{ Ex } & \multicolumn{2}{|c|}{$\mathrm{OM}$} & \multicolumn{2}{|c|}{$\mathrm{MnOx}$} & \multicolumn{2}{|c|}{ AFeOx } & \multicolumn{2}{|c|}{ CFeOx } & \multicolumn{2}{|l|}{$\mathrm{R}$} & \multirow{2}{*}{$\frac{\mathrm{T}}{\mathrm{Mgkg}}$} \\
\hline & & $\mathrm{mg} \mathrm{kg}^{-1}$ & $\%$ & $\mathrm{mg} \mathrm{kg}^{-1}$ & $\%$ & $\mathrm{mg} \mathrm{kg}^{-1}$ & $\%$ & $\mathrm{mg} \mathrm{kg}^{-1}$ & $\%$ & $\mathrm{mg} \mathrm{kg}^{-1}$ & $\%$ & $\mathrm{mg} \mathrm{kg}^{-1}$ & $\%$ & \\
\hline & & --- & 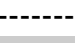 & 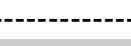 & $\cdots$ & $-v$ & out & $\operatorname{ming}$ & & $\cdots$ & $\cdots$ & - & ---- & ----. \\
\hline \multirow[t]{3}{*}{$\mathrm{LV}_{1}$} & 0.0 & 0.0 & 0 & 1.4 & 3 & 0.0 & 0 & 1.4 & 3 & 2.3 & 5 & 38.2 & 88 & 43.3 \\
\hline & 20.0 & 0.0 & 0 & 10.5 & 15 & 0.7 & 1 & 7.7 & 11 & 5.9 & 9 & 44.7 & 64 & 69.5 \\
\hline & 40.0 & 0.4 & 0 & 21.0 & 23 & 1.9 & 2 & 13.9 & 15 & 11.3 & 12 & 43.4 & 47 & 91.9 \\
\hline \multirow[t]{3}{*}{$\mathrm{LV}_{2}$} & 0.0 & 0.0 & 0 & 4.1 & 4 & 2.5 & 2 & 4.1 & 4 & 6.4 & 6 & 85.7 & 83 & 102.8 \\
\hline & 20.0 & 0.0 & 0 & 10.2 & 9 & 6.4 & 6 & 7.7 & 7 & 8.5 & 7 & 81.9 & 71 & 114.8 \\
\hline & 40.0 & 1.4 & 1 & 20.1 & 14 & 1.8 & 8 & 12.3 & 8 & 10.3 & 7 & 91.8 & 62 & 147.8 \\
\hline \multirow[t]{3}{*}{$\mathrm{LV}_{3}$} & 0.0 & 0.2 & 0 & 7.9 & 6 & 2.2 & 2 & 5.1 & 4 & 7.9 & 6 & 101.9 & 81 & 125.4 \\
\hline & 20.0 & 1.3 & 1 & 13.6 & 9 & 3.8 & 2 & 7.9 & 5 & 9.8 & 6 & 116.0 & 6 & 152.3 \\
\hline & 40.0 & 1.8 & 1 & 21.7 & 12 & 6.4 & 4 & 11.1 & 6 & 11.3 & 6 & 126.0 & 71 & 178.3 \\
\hline \multirow[t]{3}{*}{$\mathrm{LVA}_{1}$} & 0.0 & 0.0 & 0 & 1.1 & 7 & 0.0 & 0 & 0.3 & 2 & 0.9 & 6 & 14.1 & 86 & 16.5 \\
\hline & 20.0 & 3.3 & 9 & 12.6 & 35 & 3.1 & 9 & 2.1 & 6 & 3.3 & 9 & 12.0 & 33 & 36.4 \\
\hline & 40.0 & 3.8 & 7 & 28.4 & 56 & 3.7 & 7 & 3.7 & 7 & 3.6 & 7 & 7.6 & 15 & 50.7 \\
\hline \multirow[t]{3}{*}{ LVA $_{2}$} & 0.0 & 0.1 & 1 & 2.7 & 12 & 0.0 & 0 & 1.1 & 5 & 1.5 & 7 & 16.3 & 75 & 21.7 \\
\hline & 20.0 & 0.9 & 2 & 6.2 & 15 & 0.8 & 2 & 7.2 & 18 & 6.8 & 17 & 19.2 & 47 & 41.1 \\
\hline & 40.0 & 1.3 & 2 & 13.6 & 24 & 1.1 & 2 & 12.5 & 22 & 10.1 & 17 & 19.1 & 33 & 57.7 \\
\hline \multirow[t]{3}{*}{$\mathrm{LVA}_{3}$} & 0.0 & 0.0 & 0 & 1.4 & 12 & 0.5 & 4 & 0.4 & 3 & 1.8 & 15 & 7.6 & 65 & 11.7 \\
\hline & 20.0 & 0.1 & 0 & 13.3 & 26 & 1.5 & 3 & 4.7 & 9 & 14.8 & 29 & 17.5 & 34 & 52.0 \\
\hline & 40.0 & 0.4 & 0 & 25.9 & 27 & 3.0 & 3 & 10.1 & 11 & 27.4 & 29 & 27.6 & 29 & 94.5 \\
\hline \multicolumn{2}{|l|}{ Mean } & 0.8 & 1.4 & 12.0 & 17 & 2.7 & 3 & 6.3 & 8 & 8.0 & 11 & 48.4 & 59 & 78.2 \\
\hline \multicolumn{2}{|l|}{ C.V.(\%) } & 10.0 & & 9.7 & & 5.6 & & 7.9 & & 8.6 & & 7.5 & & 4.7 \\
\hline \multirow{3}{*}{$\mathrm{LV}_{1}$} & 0.0 & 0.0 & 0 & 1.7 & 4 & 0.0 & 0 & 1.8 & 4 & 1.7 & 4 & 38.1 & 88 & 43.3 \\
\hline & 20.0 & 0.0 & 0 & 10.2 & 15 & 0.9 & 1 & 7.5 & 11 & 5.1 & 7 & 45.8 & 66 & 69.5 \\
\hline & 40.0 & 0.2 & 0 & 17.5 & 19 & 2.9 & 3 & 15.4 & 17 & 9.3 & 10 & 46.6 & 51 & 91.9 \\
\hline \multirow[t]{3}{*}{$\mathrm{LV}_{\text {, }}$} & 0.0 & 0.0 & 0 & 1.4 & 1 & 4.2 & 4 & 4.5 & 4 & 3.2 & 3 & 89.5 & 87 & 102.8 \\
\hline & 20.0 & 0.0 & 0 & 3.9 & 3 & 10.0 & 9 & 8.2 & 7 & 4.8 & 4 & 87.9 & 77 & 114.8 \\
\hline & 40.0 & 0.0 & 0 & 4.8 & 3 & 17.6 & 12 & 9.8 & 7 & 6.3 & 4 & 109.3 & 74 & 147.8 \\
\hline \multirow[t]{3}{*}{$\mathrm{LV}_{3}$} & 0.0 & 0.0 & 0 & 3.5 & 3 & 5.4 & 4 & 3.9 & 3 & 8.2 & 7 & 104.4 & 83 & 125.4 \\
\hline & 20.0 & 0.2 & 0 & 8.0 & 5 & 10.6 & 7 & 7.4 & 5 & 11.1 & 7 & 115.0 & 76 & 152.3 \\
\hline & 40.0 & 0.4 & 0 & 15 & 8 & 16.9 & 9 & 9.3 & 5 & 14.7 & 8 & 122.0 & 68 & 178.3 \\
\hline LVA $_{1}$ & 0.0 & 0.0 & 0 & 0.4 & 2 & 0.7 & 4 & 0.4 & 2 & 0.2 & 1 & 14.8 & 90 & 16.5 \\
\hline & 20.0 & 0.4 & 1 & 7.0 & 19 & 7.1 & 20 & 5.1 & 14 & 0.9 & 2 & 15.9 & 44 & 36.4 \\
\hline & 40.0 & 0.9 & 2 & 13.9 & 27 & 12.1 & 24 & 10.6 & 21 & 1.6 & 3 & 11.6 & 23 & 50.7 \\
\hline LVA $_{2}$ & 0.0 & 0.0 & 0 & 0.1 & 0 & 0.1 & 0 & 1.4 & 6 & 0.8 & 4 & 19.3 & 89 & 21.7 \\
\hline & 20.0 & 0.4 & 1 & 2.6 & 6 & 1.4 & 3 & 6.5 & 16 & 8.3 & 20 & 21.9 & 53 & 41.1 \\
\hline & 40.0 & 0.5 & 1 & 5.4 & 9 & 3.4 & 6 & 11.6 & 20 & 13.5 & 23 & 23.3 & 40 & 57.7 \\
\hline LVA $_{3}$ & 0.0 & 0.0 & 0 & 1.1 & 9 & 0.2 & 2 & 0.2 & 2 & 2.3 & 20 & 7.9 & 68 & 11.7 \\
\hline & 20.0 & 0.3 & 1 & 9.0 & 17 & 1.3 & 3 & 1.9 & 4 & 16.4 & 32 & 23.1 & 44 & 52.0 \\
\hline & 40.0 & 0.3 & 0 & 19.4 & 21 & 2.3 & 2 & 5.1 & 5 & 46.2 & 49 & 21.2 & 22 & 94.5 \\
\hline Mean & & 0.2 & 0 & 6.9 & 10 & 5.4 & 6 & 6.1 & 9 & 8.6 & 12 & 51 & 63 & 78.2 \\
\hline C.V.(\%) & & 17.5 & & 5.5 & & 12.0 & & 6.7 & & 6.9 & & 7.0 & & 4.7 \\
\hline
\end{tabular}

LV 1 - Rhodic Haplustox; LV 2 - Rhodic Haplustox; LV 3 - Rhodic Haplustox; LVA - Typic Haplustox; LVA - Typic Haplustox; LVA - - Humic Haplustox 
also observed by Atanossova \& Okazaki (1997). The importance of organic matter as the main reservoir of potentially available $\mathrm{Cu}$ for plants was reported (McLaren \& Crawford, 1973a; Shuman, 1985; Sims, 1986). It seems that the OM fraction, in equilibrium with the $\mathrm{AFeOx}$ and $\mathrm{CFeOx}$ fractions, is responsible for supplying $\mathrm{Cu}$ to the soil solution under intensive cultivation, when the existing $\mathrm{Cu}$ is insufficient for maintaining adequate plant growth. The organic matter seems to be a source of specific sites for Cu complexation in the soil (McLaren \& Crawford, 1973a, b), due to the affinity of the $\mathrm{Cu}$ ion to form inner sphere complexes with humic substances (McBride, 1994).

The increase in $\mathrm{pH}$ due to liming resulted in a reduction of $\mathrm{Cu}$ in the Exchangeable (Ex) fraction and, mainly, in the Organic Matter (OM) fraction, with Cu being transferred to $\mathrm{Mn}$ and $\mathrm{Fe}$ Oxide fractions, which retained $27 \%$ of the Total $\mathrm{Cu}$ (Table 2). Similar results were observed by Jarvis (1981) and Sims (1986) and were, probably, due to a specific adsorption process which would cause a decrease in $\mathrm{Cu}$ availability. These results for $\mathrm{Cu}$ content in the fractions suggest an equilibrium for $\mathrm{Cu}$ distribution in the Exchangeable, Organic Matter, and Oxide fractions, which would be modified with $\mathrm{Cu}$ being transferred to the more available fractions Ex and OM, as $\mathrm{pH}$ is reduced. The Mn Oxide fraction presented, proportionally, the higher increment in the $\mathrm{Cu}$ adsorption. Manganese oxides have particularly high selectivity for $\mathrm{Cu}$ which indicates that covalent bonds have important contribution for $\mathrm{Cu}$ adsorption (McBride, 1994). McLaren \& Crawford (1973b) concluded that Mn oxides were the dominant mineral constituents in the specific adsorption of $\mathrm{Cu}$ by soils. For more weathered soils, however, the Fe oxides are found in higher concentrations and become, quantitatively, more important for $\mathrm{Cu}$ adsorption (Table 2).

An important factor to be considered concerning the $\mathrm{Cu}$ retention by soil fractions is the reaction time between the element and the soil. A more extended time of equilibrium with the soil would result in more stable forms of $\mathrm{Cu}$ in the presence of crystalline oxides since the reaction could continue slowly due to the diffusion of adsorbed ions into the interior of the particles (Barrow, 1993). In the present work this was observed for the soils which did not receive liming nor $\mathrm{Cu}$ addition (Table 2). These results demonstrate the importance of the time in the transformations of the added $\mathrm{Cu}$ to the soils and indicate that in soils fertilized with $\mathrm{Cu}$ the residual effect of the fertilizer decreases with its residing time in the soil, as observed by Levesque \& Mathur (1986). This effect is incremented by liming.

In soils that did not receive lime, the extractors Mehlich-1, Mehlich-3 and DTPA yielded low contents of $\mathrm{Cu}$ from the humic LVA3 soil (Table 3) which indicates a high stability of the linking between $\mathrm{Cu}$ and Organic matter. On the other hand, in treatments with liming, at higher $\mathrm{pH}$, the elevated contents of Cu extracted by DTPA and EDTA suggest that these extractors compete strongly with the organic matter for complexation of $\mathrm{Cu}$, on these conditions. This happens because the stability of the complexes micronutrient-chelates is highly $\mathrm{pH}$ dependent (Inskeep \& Baham, 1983; Stevenson \& Fitch,1989).

There was no correlation between the clay contents of the soils and the slopes of the $\mathrm{Cu}$ recovered/Cu added curves, since the extractions were performed in the soils without liming (Table 4). This is, probably, due to differences in organic matter content among the soils and to the higher affinity between $\mathrm{Cu}$ and organic compounds as compared to the mineral surfaces, as observed by Narwal \& Singh (1998). The remaining-P (Alvarez V. et al., 2000) is a measurement that may be used as a parameter to evaluate the clay quantity and clay quality of the soil and has good correlation with the adsorption process. Therefore, the slopes of the Cu recovered/Cu added curves may be better correlated to the remaining-P than to the clay content which is only quantitative. In limed soils, the slopes of the $\mathrm{Cu}$ recovered/Cu added curves were negatively correlated to Cu content extracted by Mehlich-3, DTPA and EDTA, but not with those extracted by Mehlich-1. This indicates that the recovering rate of $\mathrm{Cu}$ by Mehlich-1 presented low sensibility in relation to soil clay content.

The susceptibility of the soil fraction to the extractor, evaluated by correlation, shows, in general, that the smaller correlations are obtained for the less stable fractions (Crystalline Fe oxides and Residual) for all extractors (Table 5). This indicates that the extractors remove, preferentially, the $\mathrm{Cu}$ located in the more promptly available sites. Micronutrients linked to Crystalline $\mathrm{Fe}$ oxides are found, mostly, occluded (Shuman, 1988) whereas those related to the Residual fraction are found associated to silicated minerals, resistant sulphydes, and refractory organic materials (Narwal \& Singh, 1998). The Crystalline Fe oxides and Residual fractions are chemically and biologically stable.

The Organic Matter fraction presented better correlation with $\mathrm{Cu}$ content extracted with Mehlich-3 and DTPA, with and without liming (Table 5) which indicates that, in some way, $\mathrm{Cu}$ is being dissolved mainly from this fraction by these extractors. These results corroborate to the statement of McLaren \& Crawford (1973a) that organic matter is the main reservoir of $\mathrm{Cu}$ availability for plants. In limed soils, however, Mehlich-3 was more sensible for the transference of $\mathrm{Cu}$ to the Amorphous $\mathrm{Fe}$ Oxides and the Manganese Oxide fractions as compared to the DTPA extractor. Mehlich-1 did not present selectivity for $\mathrm{Cu}$ extraction from any particular fraction and the correlation coefficients were similar among the fractions for the soils without liming; for limed soils, Mehlich-1 extracted Cu linked, mainly, to amorphous Fe oxides and Mn oxides, probably, due to its high acidity. Mehlich-1 has been criticized by the fact that it might extract non available forms of nutrients linked to specific adsorption sites and its high acidity extracts $\mathrm{Cu}$ linked to hydroxides and carbonates which are not available to plants, facts that would limit its utilization for acid soils.

The Organic Matter fraction presented better correlation with $\mathrm{Cu}$ content extracted with Mehlich-3 and 
DTPA, with and without liming (Table 5) which indicates that, in some way, $\mathrm{Cu}$ is being dissolved mainly from this fraction by these extractors. These results corroborate to the statement of McLaren \& Crawford (1973a) that organic matter is the main reservoir of $\mathrm{Cu}$ availability for plants. In limed soils, however, Mehlich-3 was more sensible for the transference of $\mathrm{Cu}$ to the Amorphous $\mathrm{Fe}$ Oxides and the Manganese Oxide fractions as compared to the DTPA

Table 3 - Copper extracted by Mehlich-1 (M-1), Mehlich-3 (M-3), DTPA and EDTA from samples of six soil types from Minas Gerais, Brazil which received three rates of $\mathrm{Cu}$, with and without liming, and the respective slopes of the recovered $\mathrm{Cu} /$ added Cu curves $\left(\mathrm{mg} \mathrm{dm}^{-3} / \mathrm{mg} \mathrm{dm}^{-3}\right)$.

\begin{tabular}{|c|c|c|c|c|c|c|c|c|c|}
\hline \multirow{2}{*}{ Soil } & \multirow[t]{2}{*}{ Rate } & \multicolumn{2}{|c|}{$M-1$} & \multicolumn{2}{|c|}{ M-3 } & \multicolumn{2}{|c|}{ DTPA } & \multicolumn{2}{|c|}{ EDTA } \\
\hline & & $\mathrm{mg} \mathrm{dm}^{-3}$ & Slope & $\mathrm{mg} \mathrm{dm}^{-3}$ & Slope & $\mathrm{mg} \mathrm{dm}^{-3}$ & Slope & $\mathrm{mg} \mathrm{dm}^{-3}$ & Slope \\
\hline & $\ldots-$ & 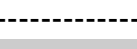 & the & $V$ & out Lim & - & - &.- & 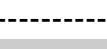 \\
\hline \multirow[t]{3}{*}{$\mathrm{LV}_{1}$} & 0 & 0.96 & & 1.76 & & 1.31 & & 1.42 & \\
\hline & 20 & 10.83 & & 10.16 & & 8.98 & & 11.92 & \\
\hline & 40 & 22.02 & 0.53 & 21.79 & 0.50 & 18.55 & 0.43 & 23.28 & 0.55 \\
\hline \multirow[t]{3}{*}{$\mathrm{LV}_{2}$} & 0 & 7.62 & & 4.44 & & 5.55 & & 7.59 & \\
\hline & 20 & 21.28 & & 14.27 & & 13.59 & & 18.86 & \\
\hline & 40 & 40.81 & 0.83 & 24.79 & 0.51 & 24.50 & 0.47 & 35.66 & 0.70 \\
\hline \multirow[t]{3}{*}{$\mathrm{LV}_{3}$} & 0 & 10.19 & & 6.89 & & 7.87 & & 11.21 & \\
\hline & 20 & 29.67 & & 17.59 & & 16.54 & & 25.47 & \\
\hline & 40 & 45.07 & 0.87 & 24.78 & 0.45 & 25.21 & 0.43 & 44.54 & 0.83 \\
\hline \multirow[t]{3}{*}{$\mathrm{LVA}_{1}$} & 0 & 0.57 & & 0.66 & & 0.62 & & 0.69 & \\
\hline & 20 & 20.34 & & 14.61 & & 9.83 & & 14.64 & \\
\hline & 40 & 41.71 & 1.03 & 34.18 & 0.84 & 22.67 & 0.55 & 28.25 & 0.69 \\
\hline \multirow[t]{3}{*}{$\mathrm{LVA}_{2}$} & 0 & 0.46 & & 0.60 & & 0.28 & & 0.62 & \\
\hline & 20 & 9.80 & & 6.08 & & 5.17 & & 13.04 & \\
\hline & 40 & 22.94 & 0.56 & 14.43 & 0.35 & 12.90 & 0.31 & 20.18 & 0.49 \\
\hline \multirow[t]{3}{*}{$\mathrm{LVA}_{3}$} & 0 & 0.38 & & 0.31 & & 0.52 & & 0.47 & \\
\hline & 20 & 4.91 & & 8.25 & & 3.43 & & 14.59 & \\
\hline & 40 & 12.58 & 0.30 & 15.97 & 0.39 & 11.35 & 0.27 & 23.79 & 0.58 \\
\hline Mean & & 16.79 & 0.69 & 12.31 & 0.51 & 10.49 & 0.41 & 15.84 & 0.64 \\
\hline C.V. (\%) & & 9.47 & & 13.30 & & 10.66 & & 13.04 & \\
\hline
\end{tabular}

\begin{tabular}{|c|c|c|c|c|c|c|c|c|c|}
\hline \multirow[t]{3}{*}{$\mathrm{LV}_{1}$} & 0 & 0.20 & & 1.15 & & 0.87 & & 2.14 & \\
\hline & 20 & 7.14 & & 9.39 & & 5.18 & & 16.74 & \\
\hline & 40 & 17.39 & 0.43 & 21.65 & 0.51 & 14.28 & 0.33 & 31.09 & 0.72 \\
\hline \multirow[t]{3}{*}{$\mathrm{LV}_{2}$} & 0 & 6.66 & & 5.38 & & 3.74 & & 10.20 & \\
\hline & 20 & 22.19 & & 14.78 & & 7.58 & & 26.73 & \\
\hline & 40 & 38.66 & 0.80 & 24.22 & 0.47 & 17.29 & 0.34 & 45.82 & 0.89 \\
\hline \multirow[t]{3}{*}{$\mathrm{LV}_{3}$} & 0 & 9.46 & & 6.34 & & 5.64 & & 10.23 & \\
\hline & 20 & 27.30 & & 16.96 & & 14.11 & & 28.16 & \\
\hline & 40 & 39.10 & 0.74 & 32.45 & 0.62 & 27.59 & 0.55 & 45.46 & 0.88 \\
\hline \multirow[t]{3}{*}{ LVA $_{1}$} & 0 & 1.49 & & 1.15 & & 0.29 & & 0.62 & \\
\hline & 20 & 25.49 & & 14.58 & & 8.28 & & 22.09 & \\
\hline & 40 & 37.33 & 0.90 & 29.70 & 0.71 & 16.49 & 0.40 & 47.98 & 1.18 \\
\hline \multirow[t]{3}{*}{$\mathrm{LVA}_{2}$} & 0 & 0.23 & & 0.30 & & 0.35 & & 0.37 & \\
\hline & 20 & 7.47 & & 8.56 & & 3.00 & & 12.20 & \\
\hline & 40 & 18.47 & 0.46 & 14.40 & 0.35 & 10.42 & 0.25 & 25.94 & 0.64 \\
\hline \multirow[t]{3}{*}{$\mathrm{LVA}_{3}$} & 0 & 0.18 & & 0.65 & & 0.75 & & 0.48 & \\
\hline & 20 & 3.76 & & 10.29 & & 10.45 & & 15.26 & \\
\hline & 40 & 10.81 & 0.27 & 23.52 & 0.57 & 24.85 & 0.60 & 39.80 & 0.98 \\
\hline Mean & & 15.18 & 0.60 & 13.08 & 0.54 & 9.51 & 0.41 & 21.18 & 0.88 \\
\hline C.V. (\%) & & 14.24 & & 9.80 & & 14.02 & & 5.42 & \\
\hline
\end{tabular}

LV $_{1}$ - Rhodic Haplustox; LV 2 - Rhodic Haplustox; LV ${ }_{3}$ - Rhodic Haplustox; LVA - Typic Haplustox; LVA - Typic Haplustox; LVA 3 - Humic Haplustox 
Table 4 - Simple linear correlation coefficients between soil characteristics and slopes for the recovering curve obtained for Cu extracted by Mehlich-1 (M1), Mehlich-3 (M-3), DTPA and EDTA, with and without liming.

\begin{tabular}{|c|c|c|c|c|}
\hline Charactristic & $M-1$ & $M-3$ & DTPA & EDTA \\
\hline & \multicolumn{4}{|c|}{ 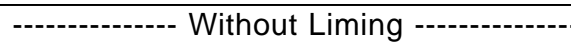 } \\
\hline $\mathrm{pH}$ & $0.00^{\mathrm{NS}}$ & $-0.33^{N S}$ & $0.08^{\mathrm{NS}}$ & $0.80^{* *}$ \\
\hline Organic Carbon & $-0.79^{\star *}$ & $-0.41^{\mathrm{NS}}$ & $-0.73^{* *}$ & $0.00^{\mathrm{NS}}$ \\
\hline Remanescent-P & $0.69^{* *}$ & $0.96^{* *}$ & $0.76^{* *}$ & $-0.56^{*}$ \\
\hline Clay & $-0.15^{N S}$ & $-0.34^{\mathrm{NS}}$ & $-0.06^{N S}$ & $-0.08^{N S}$ \\
\hline \multirow[t]{2}{*}{ CEC } & $-0.83^{* *}$ & $-0.34^{\text {NS }}$ & $-0.56^{\mathrm{NS}}$ & $-0.14^{\mathrm{NS}}$ \\
\hline & \multicolumn{4}{|c|}{ 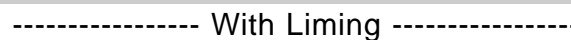 } \\
\hline $\mathrm{pH}$ & $0.60^{* *}$ & $0.27^{\mathrm{NS}}$ & $-0.49^{*}$ & $0.17^{\mathrm{NS}}$ \\
\hline Organic Carbon & $-0.76^{\star *}$ & $0.02^{\mathrm{NS}}$ & $0.64^{\star *}$ & $0.12^{\mathrm{NS}}$ \\
\hline Remanescent-P & $0.64^{* *}$ & $0.68^{* *}$ & $-0.06^{\mathrm{NS}}$ & $0.63^{* *}$ \\
\hline Clay & $-0.20^{N S}$ & $-0.69^{* *}$ & $-0.79^{* *}$ & $-0.90^{* *}$ \\
\hline CEC & $-0.03^{N S}$ & $-0.2^{*}$ & $-0.48^{* *}$ & $-0.45^{N S}$ \\
\hline
\end{tabular}

Table 5 - Simple linear correlation coefficients between $\mathrm{Cu}$ contents extracted by Mehlich-1 (M-1), Mehlich3 (M-3), DTPA and EDTA and $\mathrm{Cu}$ in fractions Exchangeable (Ex), Organic Matter (OM), Manganese Oxides (MnOx), Amorphous Fe Oxides, Crystalline Fe Oxides, Residual (R), and Total $(T)$ in six soil types, with liming (with) and without liming (without).

\begin{tabular}{|c|c|c|c|c|c|c|c|c|}
\hline Extractor & Liming & Ex & $\mathrm{OM}$ & $\mathrm{MnOx}$ & AFeOx & $\mathrm{CFeOx}$ & $R$ & $\mathrm{~T}$ \\
\hline \multirow[t]{2}{*}{$\bar{M}-1$} & Without & $0.70^{* \star}$ & $0.78^{\star \star}$ & $0.76^{* *}$ & $0.61^{\star *}$ & $0.23 \mathrm{NS}$ & $0.47^{* *}$ & $0.66^{* \star}$ \\
\hline & With & $0.35^{\star \star}$ & $0.46^{\star \star}$ & $0.93^{* *}$ & $0.69^{* *}$ & $0.06 \mathrm{NS}$ & $0.47^{* *}$ & $0.62^{* *}$ \\
\hline \multirow[t]{2}{*}{$M-3$} & Without & $0.71^{* *}$ & $0.91^{* \star}$ & $0.65^{* *}$ & $0.61^{* *}$ & $0.35^{* \star}$ & $0.28^{*}$ & $0.54^{* *}$ \\
\hline & With & $0.42^{* *}$ & $0.80^{\star \star}$ & $0.76^{* *}$ & $0.75^{\star *}$ & $0.42^{* *}$ & $0.32^{* *}$ & $0.61^{* *}$ \\
\hline \multirow[t]{2}{*}{ DTPA } & Without & $0.58^{* *}$ & $0.84^{\star \star}$ & $0.77^{* *}$ & $0.72^{* *}$ & $0.35^{*}$ & $0.50^{* *}$ & $0.71^{* *}$ \\
\hline & With & $0.33^{* *}$ & $0.83^{\star \star}$ & $0.66^{* *}$ & $0.58^{* *}$ & $0.65^{* *}$ & $0.36^{* *}$ & $0.66^{* *}$ \\
\hline \multirow[t]{2}{*}{ EDTA } & Without & $0.16^{\mathrm{NS}}$ & $0.53^{\star \star}$ & $0.67^{* *}$ & $0.75^{\star *}$ & $0.54^{* *}$ & $0.59^{* *}$ & $0.75^{* *}$ \\
\hline & With & $0.38^{* \star}$ & $0.75^{\star \star}$ & $0.78^{* *}$ & $0.76^{\star *}$ & $0.43^{* *}$ & $0.34^{* *}$ & $0.62^{* *}$ \\
\hline
\end{tabular}

**, *Significant at the 1 and $5 \%$ respectively; ${ }^{\text {NS }}$ Non significant.

extractor. Mehlich-1 did not present selectivity for $\mathrm{Cu}$ extraction from any particular fraction and the correlation coefficients were similar among the fractions for the soils without liming; for limed soils, Mehlich-1 extracted $\mathrm{Cu}$ linked, mainly, to amorphous Fe oxides and Mn oxides, probably, due to its high acidity. Mehlich-1 has been criticized by the fact that it might extract non available forms of nutrients linked to specific adsorption sites and its high acidity extracts $\mathrm{Cu}$ linked to hydroxides and carbonates which are not available to plants, facts that would limit its utilization for acid soils.

EDTA presented a similar behavior to Mehlich1 , including the possibility of extraction of non available forms of $\mathrm{Cu}$ due to its high concentration of compounds able to form complexes (Haynes \& Swift, 1983) and the possibility of dissolution of Fe oxides (Borggaard, 1979).

\section{REFERENCES}

ALVAREZ V., V.H.; NOVAIS, R.F.; DIAS, L.E.; OLIVEIRA, J.A. Determinação e uso do fósforo remanescente. Boletim Informativo SBCS, v.25, p.21$32,2000$.
ALLOWAY, B.J. The origins of heavy metals in soils. In: ALLOWAY, B.J. (Ed.) Heavy metals in soils. New York: John Wiley, 1990. p.29-39.

ATANASSOVA, I.; OKAZAKI, M. Adsorption-desorption characteristics of high levels of copper in soil clay fractions. Water, Air and Soil Pollution, v.98, p.213-228, 1997.

BAKER, D.E. Copper. In: ALLOWAY, B.J. (Ed.) Heavy metals in soils. New York: John Wiley, 1990. p.151-196.

BARROW, N.J. Mechanisms of reaction of zinc with soil and soil components. In: ROBSON, A.D. (Ed.). Zinc in soils and plants. Dordrecht: Kluwer Academic Publishers, 1993. p.15-31.

CHAO, T.T.; ZHOU, L. Extraction techniques for selective dissolution of amorphous iron oxides from soils and sediments. Soil Science Society of America Journal, v.47, p.224-232, 1983.

De FILIPPO, B.V.; RIBEIRO, A.C. Análise química do solo (metodologia). 2 ed. Viçosa: UFV, 1997. 26p.

EMPRESA BRASILEIRA DE PESQUISA AGROPECUÁRIA. Manual de métodos de análise de solo. 2.ed. Rio de Janeiro: EMBRAPA, CNPS, 1997. 212p.

HAYNES, R.J.; SWIFT, R.S. An evaluation of the use of DTPA and EDTA as extractants for micronutrients in moderately acid soils. Plant and Soil, v.74, p.111-122, 1983.

INSKEEP, W.P.; BAHAM, J. Competitive complexation of $\mathrm{Cd}$ and $\mathrm{Cu}$ by watersoluble organic ligands and Na-montmorillonite. Soil Science Society of America Journal, v.47, p.1109-1115, 1983.

JARVIS, S.C. Copper sorption by soils at low concentration and relation to uptake by plants. Journal of Soil Science, v.32, p.257-269, 1981.

LANTMANN, A.F.; MEURER, E.J. Estudo da eficiência de extratores para avaliação do zinco disponível do solo para o milho. Revista Brasileira de Ciência do Solo, v.6, p.131-135, 1982.

LEVESQUE, M.P.; MATHUR, S.P. Soil tests for copper, iron, manganese, and zinc in histosols: 1 . The influence of soil properties, iron, manganese, and zinc on the level and distribution of copper. Soil Science, v.142, p.153$162,1986$.

LINDSAY, W.L.; NORVELL, W.A. Development of a DTPA soil test for zinc, iron, manganese and copper. Soil Science Society of America Journal, v.42, p.421-428, 1978.

McBRIDE, M.B. Environmental chemistry of soils. New York: Oxford University Press, 1994. 406p.

McLAREN, R.G.; CRAWFORD, D.V. Studies of soil copper. I. Fractionation of copper in soils. Journal of Soil Science, v.24, p.172-181, 1973a.

McLAREN, R.G.; CRAWFORD, D.V. Studies of soil copper. II. The specific adsorption of copper by soils. Journal of Soil Science, v.24, p.445-452, 1973b.

MEHLICH, A. Mehlich-3 soil test extractant: a modification of Mehlich-2 extractant. Communications in Soil Science and Plant Analysis, v.15, p.1409-1416, 1984

MSAKY, J.J.; CALVET, R. Adsorption behavior of copper and zinc in soils: influence of $\mathrm{pH}$ on adsorption characteristics. Soil Science, v.150, p.513522, 1990

NARWAL, R.P.; SINGH, B.R. Effect of organic materials on partitioning, extractability and plant uptake of metals in alumi shale soil. Water, Air and Soil Pollution, v.103, p.405-421, 1998.

SANDERS, J.R. The effects of $\mathrm{pH}$ upon the copper and cupric ion concentrations in soil solutions. Journal of Soil Science, v.33, p.679689, 1982.

SHUMAN, L.M. Fractionation method for soil microelements. Soil Science, v.140, p.11-22, 1985.

SHUMAN, L.M. Effect of organic matter on the distribution of manganese, copper, iron, and zinc in soil fractions. Soil Science, v.146, p.192-198, 1988.

SIMS, J.T.; JOHNSON, G.V. Micronutrients soil tests. In: MORTVERDT, J.J.; COX, F.R.; SHUMAN, L.M.; WELCH, R.M. (Ed.) Micronutrients in agriculture. Madison: SSSA, 1991. p.427-472.

SIMS, J.T. Soil pH effects on the distribution and plant availability of manganese, copper, iron and zinc. Soil Science Society of America Journal, v. 50, p.367-373, 1986.

STEVENSON, F.J.; FITCH, A. Chemistry of complexation of metal ions with soil solution organics. In: HUNG, P.M., SCHNITZER, M. (Ed.) Interactions of soil minerals with natural organic and microbes. Madison: SSSA 1989. p.29-58.

URE, A. M. Methods of analysis for heavy metals in soils. In: ALLOWAY, B.J. (Ed.) Heavy metals in soils. New York: John Wiley, 1990. p.40-80.

VETTORI, L. Métodos de análise de solo. Rio de Janeiro: Ministério da Agricultura, Equipe de Pedologia e Fertilidade do Solo, 1969. 24p. (Boletim Técnico, 7).

ZHU, B.; ALVA, A.K. The chemical forms of Zn and Cu extractable by Mehlich1, Mehlich-3, and ammonium bicarbonate-DTPA extractions. Soil Science, v.156, p.251-258, 1993.

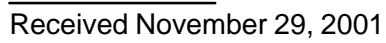

